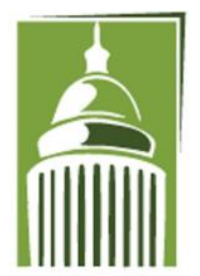

AR F

\section{Global Proceedings Repository \\ American Research Foundation}

ISSN 2476-017X

Available online at http://proceedings.sriweb.org

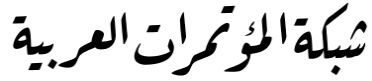

http://arab.kmshare.net/

The Ninth International Scientific Academic Conference

Under the Title "Contemporary trends in social, human, and natural sciences"

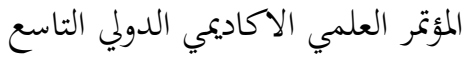

$$
\begin{aligned}
& \text { تحت عنوان "الاتحاهات المعاصرة في العلوم الاجتماعية، الانسانية، والطبيعية" } \\
& 17 \text { - } 18 \text { يوليو - تموز } 2018 \text { - اسطنبول - تركيا }
\end{aligned}
$$

http://kmshare.net/isac2018/

\title{
Evaluating the Efficiency of Sixth Class Secondary English Textbook for Iraqi Students as Seen by Teachers
}

\author{
Assist.instructor Ammar abdul Fattah Habeeb
}

Tikrit University, Salahdin Governorate, Iraq

ammar.habeeb@st.tu.edu.iq

\begin{abstract}
This study aims at evaluating the efficiency of English language textbook for the sixth class from attitudes of English teachers(male and female) in Tikrit city /Salahdin Governorate, Iraq. A questionnaire has been designed as a means to evaluate the intended textbook. It also involves 34 items which have been distributed eight categories consisting of : The Appearance of the Book, The clarification and Design, Supplementary Materials, Objectives, Subject Matters, Language Contents, Socio-cultural Content and Language Contents. Forty-four teachers (male and female) who have answered on 34 questions. A questionnaire was examined by experts in Curriculum and teaching English language as the validity tool. Many statistical means are used in this study such as Percentage and Pearson Coefficient Correlation are to authenticate the tenacity of the questionnaire items ranged between (0.392 and 1.00). Besides, Mean and Standard Deviation were adopted to analyze the results. The study indicates that evaluation's degree of the textbook was good. English teachers have considered the current textbook is appropriate to teach the Iraqi students at the sixth class in the secondary schools in spite of their suffering from a group of weaknesses , especially in teaching pronunciation which was represented the weakest point in their perspective. On the other hand, some suggestions have been reported and taken into account by designers of curriculum and academic administrators to improve the sixth class textbook.
\end{abstract}




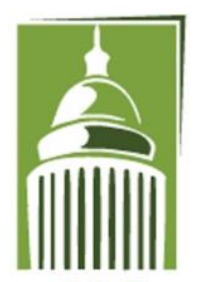

AR F

\section{Global Proceedings Repository \\ American Research Foundation}

ISSN 2476-017X

Available online at http://proceedings.sriweb.org

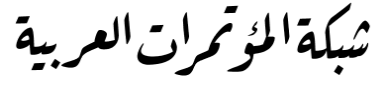

http://arab.kmshare.net/

Keywords: evaluation, Efficiency, Class, Secondary, English, Textbook, Students, Teachers.

\section{The problem}

There is said that " no book is perfect". English is used as a means of communication with people of other countries and represents an international language in all over the world. "English for Iraq" for Sixth class secondary school is a new textbook which has been taught since 2013. The eye is possible easily to be deceived by attractive artwork and colourful forms whereas some teachers encounter particularly hard to know what look for in an English textbook.

Besides, it has been noticed that some teachers are suffering from difficulties due to their teaching through the current textbook which doesn't usually describe everything about the authenticity of learning, face many problems in handing with the current book. Since some teachers encounter many problems in terms of teaching English in secondary school. It is supposed that the inadequacies instructions and curriculum are resulted from this predicament (Jahangard,2007 as cited in Sabzblipor and Koosha,2014:215). On the other side, Grant(1987:8) assumed that "perfect book does not exit" for language learning in all aspects of situations. However, it is very necessary to evaluate EFL materials for providing suitability in context and language classroom situations.

Williams(1983:251) believed that the textbook can present examples of common difficulties ; but, there are specific problems to various language groups which are left for the teachers to deal with. It has been assumed that materials that do not seem to spend great efforts learners are criticized by many respondents because of being repetitive methods and boring to grammar are among complaints. Also, a number of courses are criticized for unexpected leap of level and awkwardness unattached introductions of new language(Tomlinson,2008:47). Finally, Al-Mahrooqi and Denman (2015:291) suggested that there are many elements should be taken into consideration in evaluating the textbook such as layout $\backslash$ graphics, physical characteristics, with reference to the size of the book and authenticity as the activities can be changed

\subsection{The Value} according to students' needs and interests.

The current study may assist teachers to identify shortcomings in the textbook. It also assists the educators and the curriculum planners at the Ministry of Education to improve a new textbook.

A remarkable perspective evaluation is to see as a management of publications whereby educational markers to test strategies for making budget and allotment of sources(McDonough and Shaw,2013:74). Evaluation methods are to help teachers, should reduce the threat occasion by a demonstration of their weaknesses and strengths (Ramsden,2003:226). As the textbook has to provide appropriate guidance for the English teachers who are non-native speakers to control overall aspects of English as a foreign language. It also cannot be neglected the procedures suggested by the textbook (Williams,

\subsection{Aims of the study}

This study aims at findings:

1-the appropriateness of the textbook appearance.

2-the suitability of the textbook material.

3 -the suitability of the textbook material to socio-cultural context.

4-the appropriateness of classroom situations for teaching the textbook. 


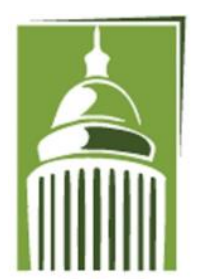

AR F

\section{Global Proceedings Repository \\ American Research Foundation}

ISSN 2476-017X

Available online at http://proceedings.sriweb.org

\subsection{Limits of the study}

This study is limited to the English Textbook "English for Iraq" for $6^{\text {th }}$ Secondary Stage. An EFL teachers(male and female) who are teaching "English for Iraq" for $6^{\text {th }}$ Secondary Grand at secondary schools in Tikrit city, Salahdin Governorate, Iraq during the academic year 2017-2018.

1.5 Definitions of Basic Terms

1- Evaluation : (Kiely and Rea-Dickins,2005: 6) defined as " a form of enquiry, ranging from research to systematic approaches to decision-making".

2- Textbook is defined as an expression of generally accepted principles in one subject, intended primarily as a basic for instruction in classroom or pupil-book-teacher situation(Brammer,1967,Laspina,1998:28 as cited in Mahmmod,2009:159).

\section{Theoritical Background \\ 2.1 The Concept of Evaluation}

Evaluation is defined as " the systematic collection and analysis of all relevant information necessary to promote improvement of a curriculum and assess its effectiveness and efficiency"(Richards and Renadya,2002:77). It is very wide term with number of different dimensions, and consequently is hard to delineate. Therefore, a textbook should not be evaluated without contract with its aims, goals, objectives, context, instructors and designers, and its main resource which makes complicated permutations (Jonson and Jonson,1998:125).

However, evaluation is a wider term than assessment and involving other processes added. These additions of process are formed to help in interpreting and representing the results are taken. So, evaluation is a difficult in order to obtain information but also a process of making decision (Nunan, 1998:118 as cited in AlSowat,2012:341). Becerra (2006:33) suggested that the process of evaluation has three essential components. The first component involves the collection information such as educational factors, background of students and learning processes. The second one is the interpretation information and comparing it with some desired goals, affairs or other information is relevant to decision. The final one or third includes a process of making decisions about instruction, textbook and students.

Spolsky and Moon(2012:140) believed that evaluation displays minus and positive points of any textbook should be included terms of illustrations, teachings aids, theme, content of language knowledge and materials. Madaus (1983:xi) mentioned that the role of evaluators are to control on many concepts are included in evaluation such as requirements, worth, goals, validity, accountability, creditability, practical value, improvement criteria. Evaluation plays an essential part of learning and teaching for teachers. It also supplies a valuable information are used for planning, managing the students, and the direction of classroom practice. It is necessary to make explicit the criteria which are used in making decisions and these decisions based on fair, reliable, informative, include set of criteria to evaluate needs of learning tasks(Dickins and Germaine,1992:4).

\subsection{Types of Evaluation}

According to Tomlinson (2003:P.p23-26) mention that evaluation has divided into three types as the following: 


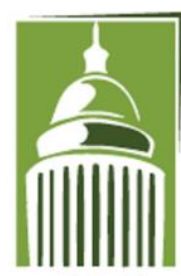

AR F

\section{Global Proceedings Repository \\ American Research Foundation}

ISSN 2476-017X

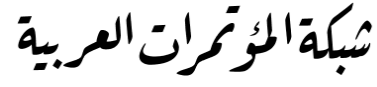

http://arab.kmshare.net/

Available online at http://proceedings.sriweb.org

a- Pre-use evaluation: It is very complex and difficult because it is no actual experience of adopting textbook and usually depends on making predictions about potential value of material.

b- Whilst-use evaluation: The second type includes measuring the value of materials. It is more valid and reliable because of using measurement instead of prediction. It is also intended that joining the textbook again a limited need involving background of students, objective of student reasons available.

c- Post-use evaluation: It generally makes up of the short-term effects and the long-term effects. The shortterm concerns with motivation, impact and achievability. The long-term involves durable learning and application. This type measures the actual effects of materials on the users and helps the administers to decide if using the same book or no in the future.

\subsection{Textbook}

The current textbook consists of eight units that deals with different topics. Each unit has a different theme and occasionally there are few exercises. Unit four is considered that initial revision and practice of skills, grammar and lexical units.(one to three ) while unit eight concerns with the final revision of units (five to seven). A textbook and activity book is separated but they are presented in the same lesson.

Also, other materials are used such as CDs, activity book, and teacher's guide are usually joined by a textbook. All of these materials have been taken into consideration in the design textbook.

The sixth grade textbook is entitled "English for Iraq" published by ministry of Education which designed the series of "English for Iraq" . Indeed, the textbook focuses on basically on reading and writing ,however, the teacher must complete with listening and speaking activities. The textbook for evaluation was selected "English for Iraq" series. The series are set of EFL textbooks from intermediate to secondary levels.

However, each unit involves topic, pronunciation, has been presented in the initial page, grammar, function, vocabulary as well as four skills. The authors believed that subjects probably motivate students to learn English and enhance to develop their own strategy of treating vocabulary.

\subsection{Important Textbook}

Textbooks are very necessary resources for teachers in helping students to learn English. They represent the fundamental source of information for teacher and school education. The textbook thus becomes the main source of communication for students with the language solo from input prepared by their teacher(Azizifar et al). Agudo (2014:277) mentioned that the teachers attempt to identify judiciously and reach a familiar decision that what will be made the difference selecting the right or inappropriate one.

The vital textbook has become a great element in teaching and learning English as a foreign language to meet the needs of classroom. It has been believed that the idea of the textbook yields a type of dependency culture between teachers, students, and deduced that the exactly teaching to one of supervising a preplanned classroom incident (Littlejohn,1992:84) as cited in (Hutchinson and Torres, 1994:315). Sheldon (1988, 237) considered the textbook is the visible heart of EFL programme and represents both teachers and students

when it is being used in the EFL classroom.

3. Procedures of the Study

\subsection{Population and Sample}

The total number of the teachers' population of the study is the EFL secondary teachers of General Directate Salah din/Department of Tikrit during October 2017. It has been limited the sample, which involved 54 teachers(male and female). Ten teachers are excluded since some of them are involved in the open-ended questionnaire and others are not properly completed. The remaining 44 teachers have taken place in the 


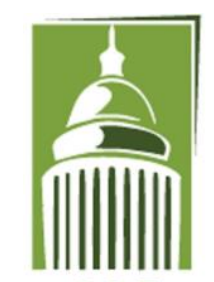

AR F

\section{Global Proceedings Repository \\ American Research Foundation}

ISSN 2476-017X

Available online at http://proceedings.sriweb.org

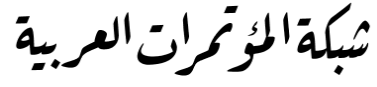

http://arab.kmshare.net/

current study. Therefore, the sample of the study is 44 teachers whose responses are analyzed and used to fulfill the aims of this study.

\subsection{The Instrument of the Study}

A questionnaire has been used as the instrument to achieve the aims of the study. It has defined as "a list of questions sent to a number of persons for their answers and which helps is obtaining standardized results that can be tabulated and treated statistically "(Pathak,2008:110).

Tomlinson $(2008,46)$ says that questionnaire supplied a number of descriptive statements of respondents who are able to select from depict a specific course. In the sense, questionnaire can be applied either on fully

\subsubsection{The Construction of the Questionnaire}

knowledge of individuals or on a group of partly to express in in words.

The construction of the questionnaire is typically consists of eight categories. Each category also involves a series of items. In order to get enough information about the EFL teachers at the secondary schools. A questionnaire has been constructed on the following sources: teachers' suggestions and Sheldon's Model. Four sections have been used and labelled as 1-Strongly disagree, 2-Disagree, 3-Agree,4-Strongly agree

\subsubsection{The Face Validity of the Questionnaire}

A commonly used definition is that " degree to which a test or instrument measures what it purports to measure"(Thomas,2011:193).Yet, validity is very important feature of the research tool because it checks directly how well the tool achieves its functions. Face validity is a fundamental and the minimum index. The questionnaire has been exposed to *the specialists as the jury members in the fields of methodology and linguistics.

The specialists have been asked to judge whether the items are valid or not. Some items have changed and others have deleted according to the specialists; views. The form of the teachers; questionnaire comprises 34 items into eight categories $: 1=5,2=5,3=3,4=6,5=3,6=3,7=4$, $8=5$.

Names of jury members arranged according to their academic address

1-Professor Hamdi H. Yousif (Ph.D.) College of Education for women

2-Assist. Prof. Abdulla H. Mousa (Ph.D.) College of Education for women

3- Assist. Prof.Madeha Saleh(Ph.D.) College of Education for women

4-Instrucror Issra B. Abd Rahman (Ph.D) College of Education for women

5-Instructor Afraa H. Sami (M.A) College of Education for women

6- Instructor Elaf S. Abdullah (M.A) College of Education for women

7-Instructor Mohammed S. Abd Waheed (M.A) College of Education for women

\begin{tabular}{|l|l|l|l|}
\hline No. & Dimension & $\begin{array}{l}\text { Number of } \\
\text { items }\end{array}$ & Percentage \\
\hline $1-$ & The Appearance of the book & 5 & 14.7 \\
$2-$ & The Clarification and Design & 5 & 14.7 \\
$3-$ & Supplementary Materials & 3 & 8.8 \\
$4-$ & Objectives & 6 & 17.6 \\
$5-$ & Subject Matters & 3 & 8.8 \\
$6-$ & Language and Content & 3 & 8.8 \\
$7-$ & Socio-cultural Content & 4 & 11.7 \\
$8-$ & Language Skills & 5 & 14.7 \\
\hline
\end{tabular}




\section{Global Proceedings Repository American Research Foundation}

ISSN 2476-017X

Available online at http://proceedings.sriweb.org

AR F

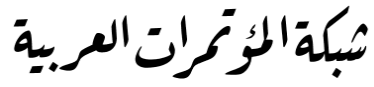

http://arab.kmshare.net/

Total

34 100

\subsubsection{The Content Validity}

Content validity is defined as " the extent to which the program instrument measures scores concept of interest"(Zumbo and Chan, 2014:14). In order to check accurate items of the questionnaire and find out the content validity after that applied to the pilot sample. The researcher has fulfilled the content validity by using "Pearson Correlation Coefficient formula".

\subsubsection{Reliability of the Questionnaire}

The tenacity of measurement while the procedure of repeating test is on persons or population (Mertler,2003:62). The administration of the questionnaire has been applied to eight teachers at the beginning of November 2017 and the retest has been conducted in the middle of November. The period time of the first and second application was two weeks. Pearson Correlation Coefficient formula has been used to obtain the data from the two applications. The result of Pearson Correlation Coefficient

\begin{tabular}{|l|l|l|l|}
\hline No. & Dimension & $\begin{array}{l}\text { Number of } \\
\text { items }\end{array}$ & Percentage \\
\hline $1-$ & The Appearance of the book & 5 & 0.392 \\
$2-$ & The Clarification and Design & 5 & 0.648 \\
$3-$ & Supplementary Materials & 3 & 0.968 \\
$4-$ & Objectives & 6 & 1.00 \\
$5-$ & Subject Matters & 3 & 0.963 \\
$6-$ & Language and Content & 3 & 0.494 \\
$7-$ & Socio-cultural Content & 4 & 0.812 \\
$8-$ & Language Skills & 5 & 0.810 \\
\hline & Total & 34 & 0.760 \\
\hline
\end{tabular}

\subsubsection{Pilot of Administration of the Questionnaire}

The pilot of the study is to involve a large number of participants for some analysis to be achieved to fix questions are asked to obtain the required data by their answers (Brace,2008:181). The pilot of the study has been conducted in which eight English teachers have been selected randomly from various secondary schools

for the pilot administration. Furthermore, they are excluded from the main sample of the study.

Results of the pilot study gives a chance to avoid mistakes which would spoil the whole administration is reduced. Moreover, it may shed light on any point of weakness in the administrative procedure.

\subsubsection{Final Administration of the Questionnaire}

The researcher has distributed to the respondents in the middle of November 2017. The teachers were asked kindly to give their opinions on the statements. Also, they were given two days to complete the questionnaire. After that the researcher collected the questionnaires personally.

4. Data Analysis and Results

To evaluate the aim of the current study which presents " Evaluating the Efficiency Sixth Class Secondary English Textbook for Iraqi Students as Seen by Teachers. The statistical means are used such as frequency, mean and standard deviation and calculated each of the essential parts of the 4.1 The Appearance of the Book questionnaire. 


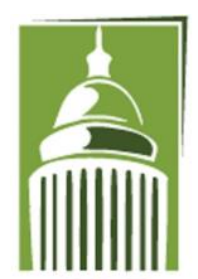

A R F

\section{Global Proceedings Repository \\ American Research Foundation}

ISSN 2476-017X

Available online at http://proceedings.sriweb.org

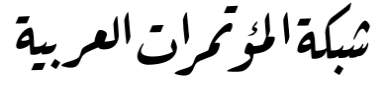

http://arab.kmshare.net/

The appearance of the book is very necessary. The students scarp to make decision by book; cover. If the book is a systematic, clearly text and attractive to encourage, facilitate negotiation of students and being interested in studying it. The answers were arranged 4 point Likert scale, from strongly disagree to strongly agree as shown in Table 1.

The Appearance of the Book Table (1)

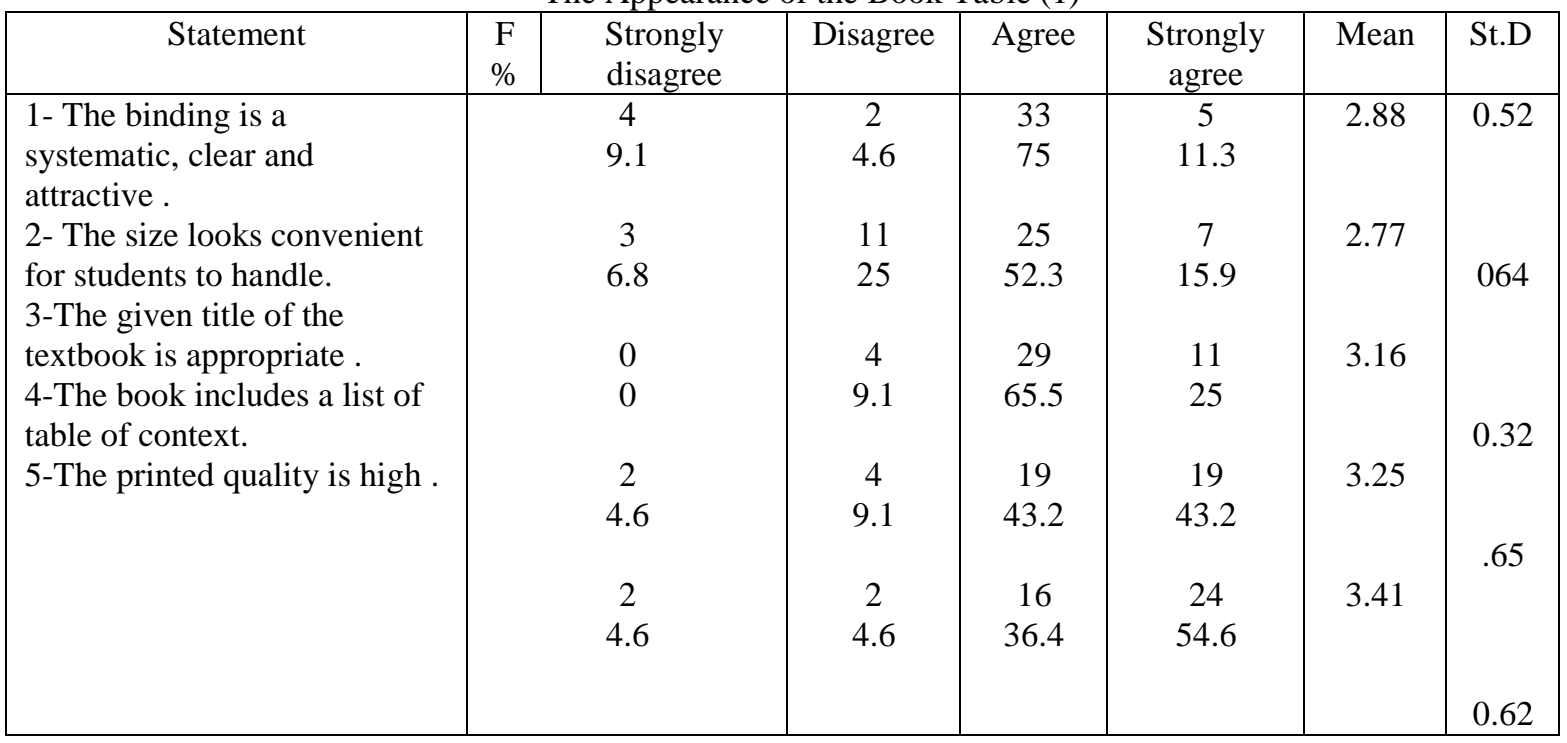

As shown in Table 1, the result details that percentage of the respondents sustain the statement, $9.1 \%$ strongly disagree and $4.6 \%$ disagree, as $75 \%$ agree and $11.3 \%$ strongly agree with the statement.

The mean score is 2.88 and standard deviation is 0.52 . This indicates that the teachers believe that of the book is systematic and attractive.

Regarding the front size, the result indicates that the respondents affirm the statement, $6.8 \%$ strongly disagreement and $25 \%$ disagree, while $52.3 \%$ and 15.9 strongly agree. The mean score is 2.77 and standard deviation is 0.64 . The majority of the teachers are favor of the font size and appropriate for students.

Concerning with the third statement of Table 1, all teachers support . No participants strongly disagree, only 4 participants disagree on the statement. The title is " English for Iraq". The result then shows that 4 participants $(9.1 \%)$ disagree while $65.9 \%$ agree and $25 \%$ strongly agree. The mean score is 3.16 and standard deviation is 0.32

Furthermore, the forth statement of the Table 1, the result details that the majority of teachers believe a book has a list of content for all subjects. Also, they are satisfied with this table of content. Only six participants were between $4.6 \%$ strongly disagree and $9.1 \%$ disagree, $43.2 \%$ agree and $43.2 \%$ strongly agree.

The mean score is 3.25 and standard deviation is 0.65 .

The question in the Table 1 indicates that the majority of responses support the statement. 9.2\% out of the population was between strongly disagree and disagree, while over $90 \%$ rate out of the population was between agree and strongly agree. The results shows that an extremely positive and are in favor of the item. The mean score is 3.41 and the standard deviation is 0.62 . 


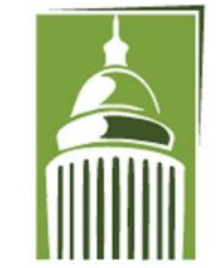

AR F

\section{Global Proceedings Repository \\ American Research Foundation}

ISSN 2476-017X

Available online at http://proceedings.sriweb.org
شبكة المؤرمَاتَ العربة

http://arab.kmshare.net/

\subsection{The Clarification and Design}

The clarification and design are very necessary characteristics that must be taken into considerations when being evaluated a textbook. These characteristics plays a fundamental role in comprehending the type text, learning and teaching more effective.

There are five criteria are designed to evaluate what extent the clarification and design are appropriate for the English for Iraq textbook. As shown in table 2.

The Clarification and Design Table (2)

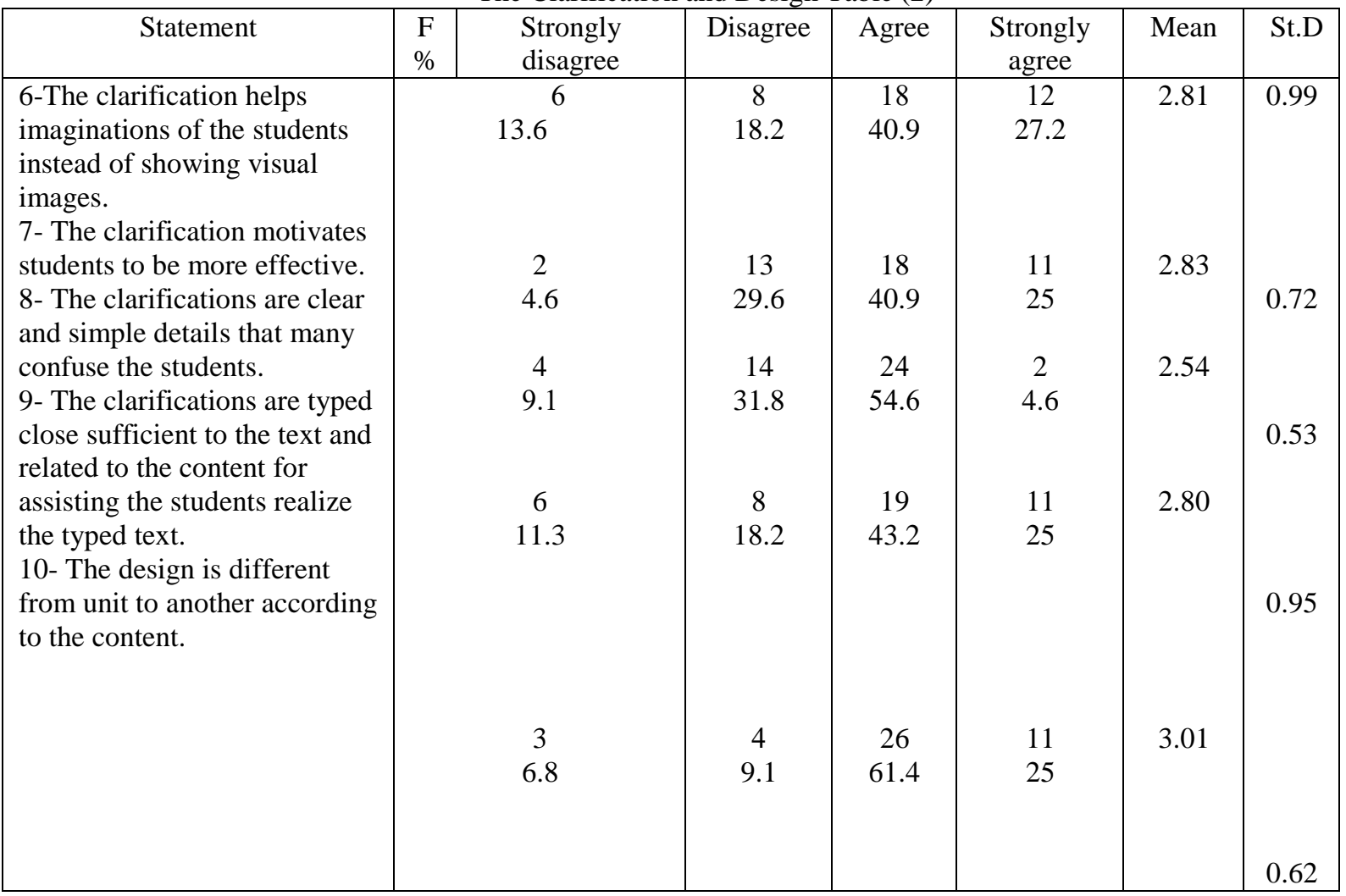

Concerning with the first statement of Table 2, the majority of teachers support it, the intended textbook makes students imagine the foreign language. The is a difference of design to perform impact, $13.6 \%$ strongly disagree and $18.2 \%$ disagree while $40.9 \%$ agree and $27 \%$ strongly agree. The mean score reaches 2.81 at a standard deviation of 0.99 .

The results reveal that the clarification motivates the students to learn more effective. $9.1 \%$ strongly disagree and $29 \%$ disagree, $40.9 \%$ agree and $25 \%$ strongly agree. The mean score is 2.83 at standard deviation of 0.72 . 


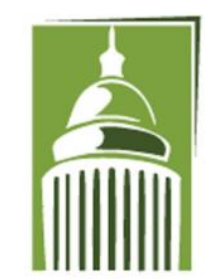

AR F

\section{Global Proceedings Repository \\ American Research Foundation}

ISSN 2476-017X

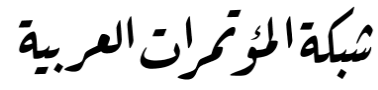

http://arab.kmshare.net/

Available online at http://proceedings.sriweb.org

Regarding the clarifications are used in the textbook in question. If there is simple and clear details make the students confused. About 4 respondents $(9.1 \%)$ strongly disagree and 14 (31.8\%) disagree, 24(54.6\%) agree and $2(4.6 \%)$ strongly agree. The mean score is 2.54 and the standard deviation is 0.53 .

It has been noticed that the majority of teachers; responses are in favor of the statement if the clarifications are typed close enough to help student to understand the typed text or not.11.3\% strongly disagree, $18.2 \%$ disagree as $43.2 \%$ agree and $25 \%$ strongly agree. The mean score is 2.80 and the standard deviation is 0.95 .

The results find out that the majority of the participants over $86 \%$ agree on the statement that the design is varied and each unit has a new topic according to the content. 3 teachers; responses $(6.8 \%)$ strongly disagree and 4 teacher; responses (9.1\%) disagree, while $27(61.4 \%)$ teachers agree on the statement as well as 11(25\%) teachers strongly agree. The mean score arrives 3.01 at a standard deviation of 0.62 .

4.3 Supplementary Materials

The role of using supplementary materials is very important in the process of teaching such as teachers; book, cassettes, CD ROM and flesh card. Furthermore, supplementary materials make students more effective and interesting in dealing with the foreign language. Also, for casing the abilities of teacher and learning of students.

Supplementary Materials Table( 3)

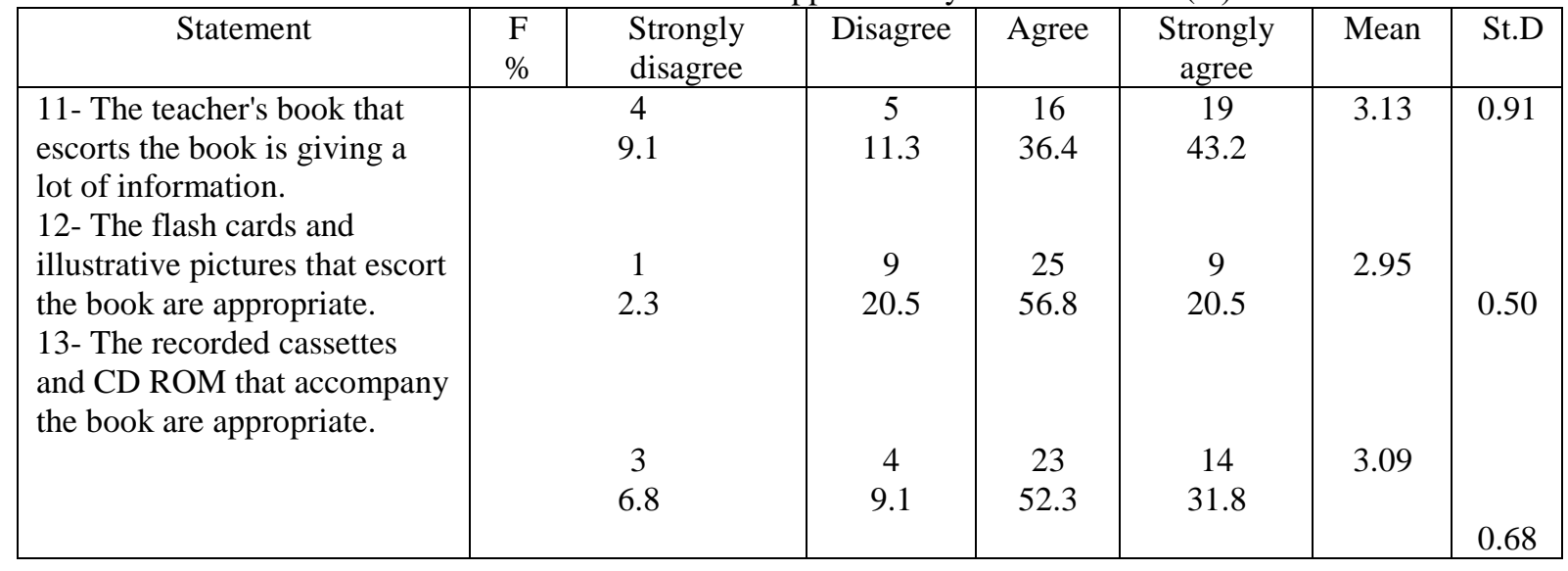

The results find out that teacher's book escorts the book gives a lot of information. Over $79 \%$ of participants strongly agree $43.2 \%$ and agree $36.4 \%$. As strongly disagree $9.1 \%$ and disagree $11.3 \%$. The mean score is 3.13 and the standard deviation is 0.91 .

Concerning with the flesh cards escort the book, the above table shows that there is complete agreement on its appropriateness. Only one (2.3\%) strongly disagree and $9(20.5 \%)$ disagree while agree $25(56.8 \%)$ and $9(20.5 \%)$ strongly agree. The mean score reaches 2.95 at a standard of 0.50 .

Regarding the appropriateness of using the recorded cassettes and CD ROM that are taken part by teachers in the classroom. The majority of answers are in favor of the statement. Less than $16 \%$ between strongly disagree and disagree. As agree 23(52.3\%) and 14 (31.8) strongly agree. It can be said more 84\% support the statement. The mean score is 3.09 while the standard deviation is 0.68 . 
ISSN 2476-017X

\subsection{Objectives}

There is not doubtful that any textbook has specific objects according to the needs and requirements of students. It must be into account that objectives have to be measureable, accurate and explicit.

Objectives Table (4)

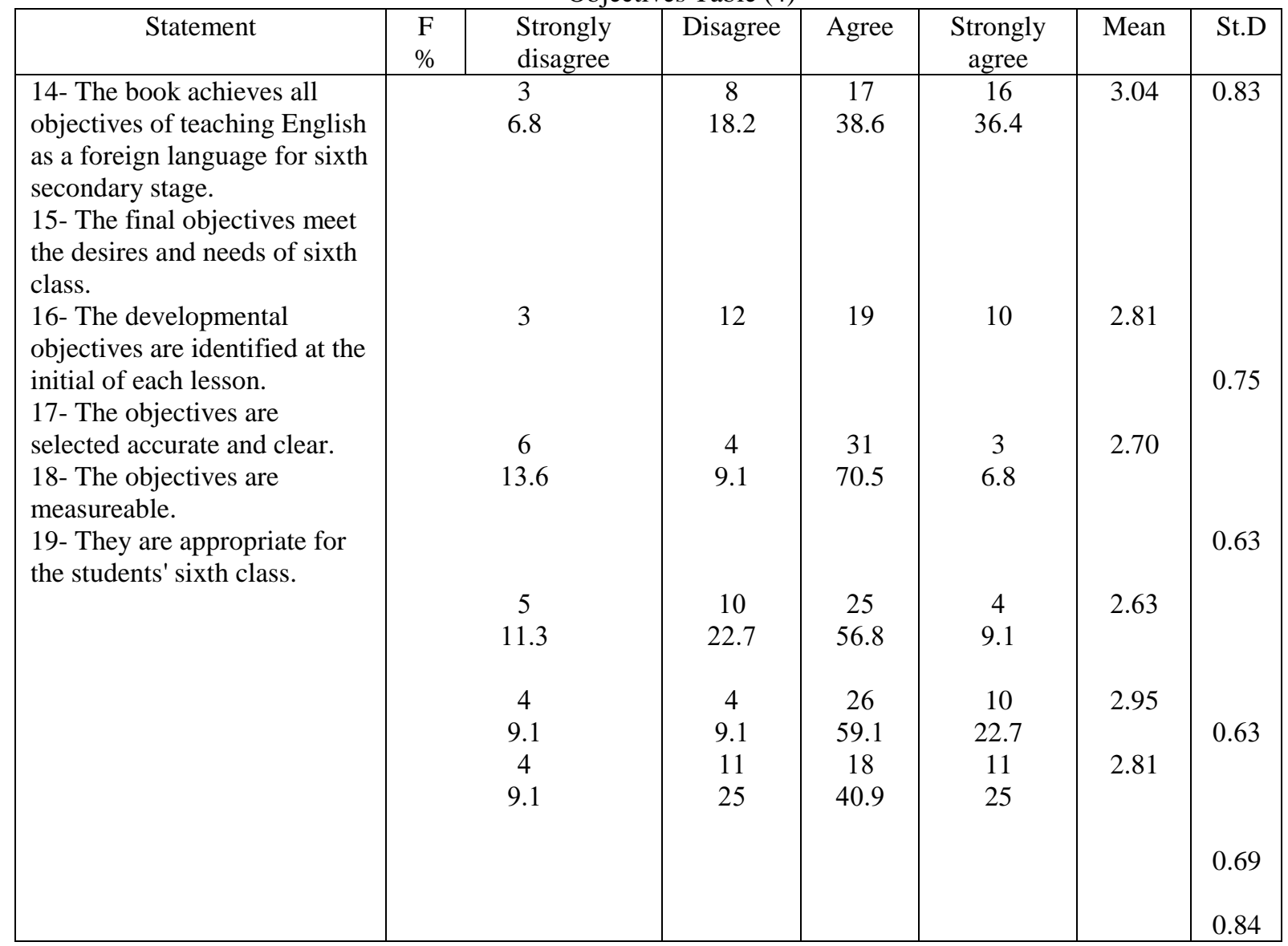

The responses of teachers are $25 \%$ believe that objectives of the current book does not fulfill, as the majority of responses believe that objectives achieve and are $75 \%$ obviously. So, the table 4 finds out the majority of responses are in favor of the statement. The mean score is 3.04 and the standard deviation is 0.83 .

Concerning with the second statement in the table 4, the participants who thought the final objectives did not meet the needs of sixth class were $34 \%$ between strongly disagree and disagree. While, the majority of participants, who believed that objectives met the sixth class's needs were more than $65 \%$ between agree and strongly agree as the above table. The mean score is 2.81 as the standard deviation is 0.75 . 


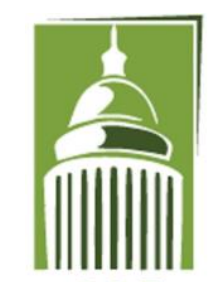

AR F

\section{Global Proceedings Repository \\ American Research Foundation}

ISSN 2476-017X

Available online at http://proceedings.sriweb.org

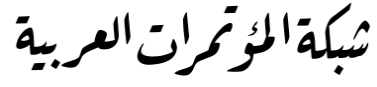

http://arab.kmshare.net/

Regarding the developmental objectives, the results details that responses confirm the statement, $6.8 \%$ strongly disagree and $9.1 \%$ disagree, while $70.5 \%$ agree and $6.8 \%$ strongly agree. The mean score reaches 2.70 at a standard of 0.63 .

The fourth statement involves accurate and clear objectives are in the textbook. The results reveal that $11.3 \%$ of answers are strongly disagree and $22.7 \%$ disagree. $56.8 \%$ agree and $9.1 \%$ strongly agree. The mean score is 2.63 and the standard deviation is 0.69 .

It has been noticed that more than $18 \%$ of responses were between strongly disagree and disagree, while the majority of them supported the statement and were more than $81 \%$ between agree and strongly agree. The mean score is 2.95 and the standard deviation is 0.69 .

The final statement in the table 4 is about the appropriateness objectives for students. $9.1 \%$ strongly disagree and $25 \%$ disagree. As 40.9 agree and $25 \%$ strongly agree. It also finds out that the results of responses supports the statement. The mean score is 2.81 and the standard deviation is 0.84 .

\subsection{Subject Matters}

The suitable subjects of the current textbook were evaluated by the question of questionnaire involving three criteria in table 5 .

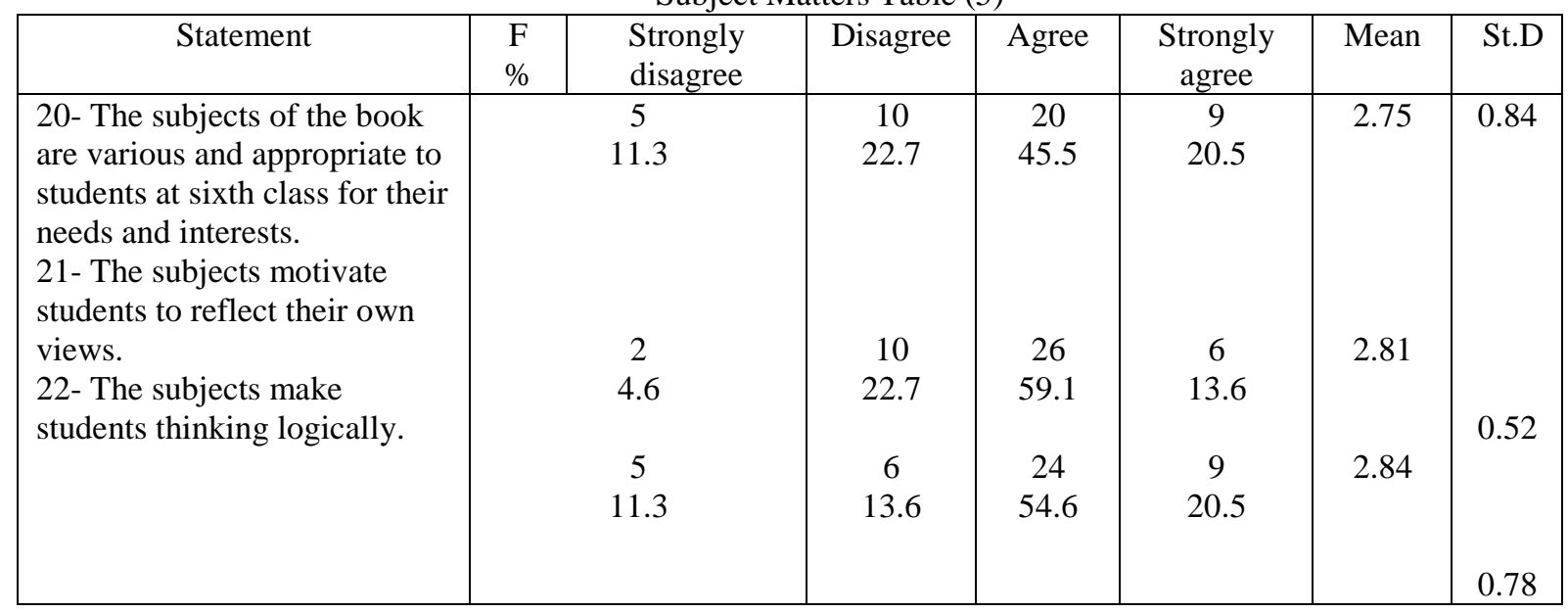

The data indicates that the teachers who rejected the first statement $34 \%$ out of total population. The majority of teachers support the statement and $66 \%$ was between agree and strongly agree . The mean score is 2.75 and standard deviation is 0.84 .

It is also interesting to be noticed that responses affirm the statement. Only $27 \%$ disagree, while over $72 \%$ out of the total population was agree. It reveals that the responses were in favor of the statement. The mean score is 2.81 and standard deviation is 0.52 .

Furthermore, the last statement as shown in table 5, strongly disagree $11.3 \%$ and $13.6 \%$ disagree. As $54.6 \%$ agree and $20.5 \%$ strongly agree. This confirms the statement. The mean score is 2.84 and the standard deviation is 0.78 . 


\section{Global Proceedings Repository American Research Foundation}

ISSN 2476-017X

Available online at http://proceedings.sriweb.org

\subsection{Language Content}

The language content is very import and must be evaluated to see if the various constituents are effective to expedite learning and teaching process. However, language content definitely makes up grammar, vocabulary and pronunciation are presented in questions as shown in Table 6.

Language Content Table (6)

\begin{tabular}{|c|c|c|c|c|c|c|c|}
\hline Statement & $\begin{array}{l}\mathrm{F} \\
\%\end{array}$ & $\begin{array}{l}\text { Strongly } \\
\text { disagree }\end{array}$ & Disagree & Agree & $\begin{array}{c}\text { Strongly } \\
\text { agree }\end{array}$ & Mean & St.D \\
\hline \multirow{6}{*}{$\begin{array}{l}\text { 23- The grammatical rules } \\
\text { formed implicitly throughout } \\
\text { the book is suitable for the } \\
\text { sixth class. } \\
\text { 24- The vocabulary are } \\
\text { appeared to be reasonable for } \\
\text { the students' of that grade. } \\
\text { 25- The book includes an } \\
\text { appropriate materials for } \\
\text { teaching pronunciation. }\end{array}$} & & 4 & 5 & 24 & 11 & 2.95 & 0.74 \\
\hline & & 9.1 & 11.3 & 54.6 & 25 & & \\
\hline & & 1 & 7 & 26 & 10 & 3.02 & \\
\hline & & 2.3 & 15.9 & 59.1 & 22.7 & & .480 \\
\hline & & $\begin{array}{c}13 \\
29.6\end{array}$ & $\begin{array}{c}13 \\
29.6\end{array}$ & $\begin{array}{c}13 \\
29.6\end{array}$ & $\begin{array}{c}5 \\
11.2\end{array}$ & 2.22 & \\
\hline & & & & & & & 1.00 \\
\hline
\end{tabular}

According to the above table, the results shows that the majority of teachers' points of view are positive and in favor of the statement. They believed that the grammatical rules are suitable for students and covers the materials. Only $9(20.4 \%)$ out of the total population teachers have rejected and dissatisfied with the statement. As the others (over 79\%) support it. The mean score is 2.95 and standard deviation is 0.74 .

The second statement involved if the vocabulary which were adopted in the textbook was reasonable for students' level. The data obtained display that majority of responses support it. $2.3 \%$ strongly disagree and $15.9 \%$ disagree. As $59.1 \%$ agree and $22.7 \%$ strongly agree. More than $80 \%$ of responses was in favor of the statement. The mean score is 3.02 and the standard deviation is 0.48 .

Regarding the suitable materials are for teaching pronunciation. The findings demonstrate that $29.6 \%$ strongly disagree, $29.6 \%$ disagree, while $29.6 \%$ agree and $11.2 \%$ strongly agree. As previously, the majority of teachers do not support it. They believe that materials which are used to teaching pronunciation is not appropriate. Over 59\% out of the total population are in favor of the statement. The mean score is 2.22 and standard deviation is 1.00 .

\subsection{Soci-Cultural Content}

The socio-cultural content elements should be evaluated in the following table. This table has four questions are asked as part of the current study.

Soci-Cultural Content Table( 7)

\begin{tabular}{|l|c|c|c|c|c|c|c|}
\hline \multicolumn{1}{|c|}{ Statement } & $\begin{array}{c}\mathrm{F} \\
\%\end{array}$ & $\begin{array}{c}\text { Strongly } \\
\text { disagree }\end{array}$ & Disagree & Agree & $\begin{array}{c}\text { Strongly } \\
\text { agree }\end{array}$ & Mean & St.D \\
\hline $\begin{array}{l}\text { 26- The book involves the } \\
\text { authentic socio-cultural } \\
\text { elements (social, political, }\end{array}$ & & $\begin{array}{c}2 \\
4.6\end{array}$ & 11 & 19 & 12 & 2.93 & 0.71 \\
\hline
\end{tabular}




\section{Global Proceedings Repository \\ American Research Foundation}

ISSN 2476-017X

Available online at http://proceedings.sriweb.org historical, geographical, religious, educational and literary).

27- The book's content has new information and images. 28- The book's content helps students to develop their personal cultural of sociocultural elements adopted. 29- The book explains positive opinion of attitude, behaviour, reaction, traditions, habits and value in the Iraqi society.

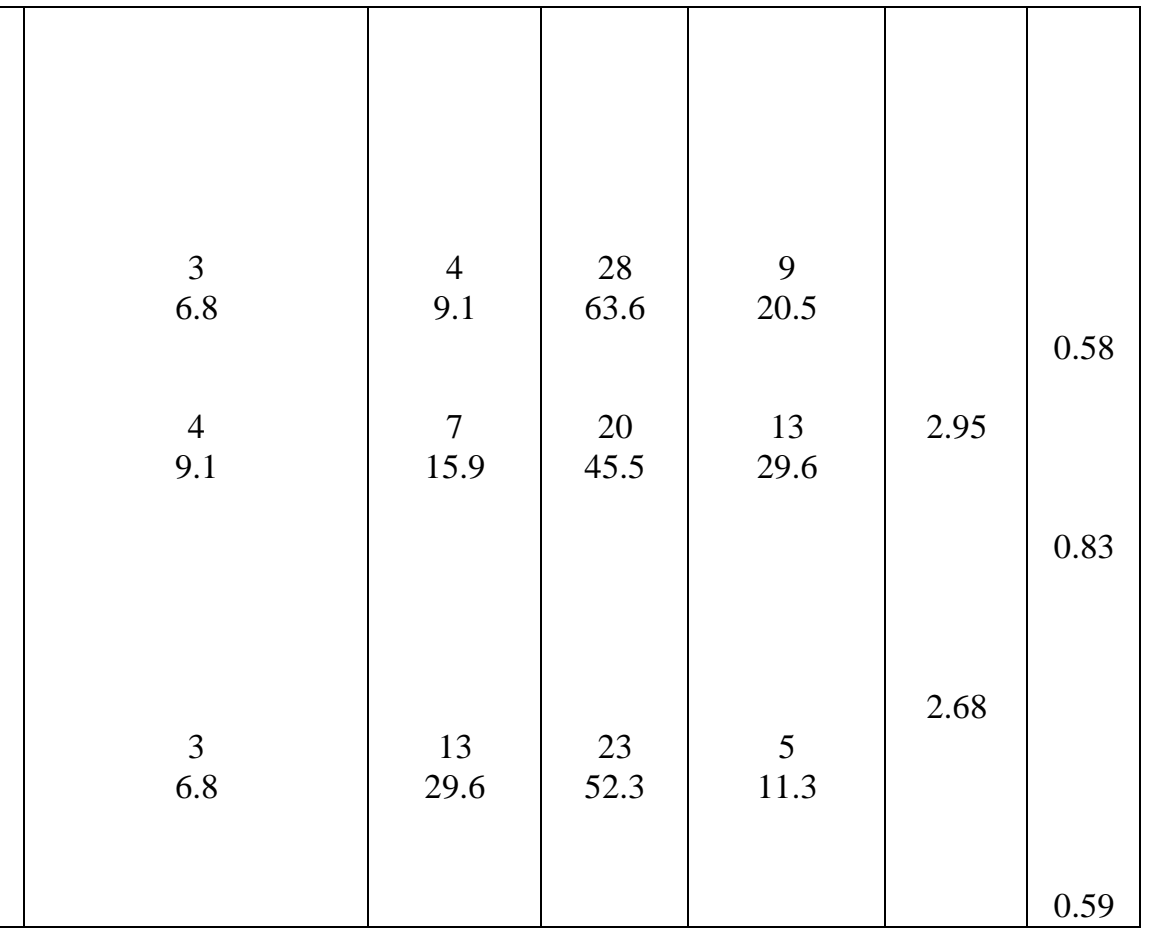

Through the table 7 reveals that responses assert on the statement. $4.6 \%$ strongly disagree and $25 \%$, as $43 \%$ agree and $27 \%$ strongly agree. The mean score is 2.93 and standard deviation is 0.71 .

There is an argument that whether the text book has images and information in the content of it. Very limited responses are between strongly disagree $(6.8 \%)$ and disagree $(9.1)$. While the majority of teachers' responses are in favor of the statement whereas $63.6 \%$ agree and $20.5 \%$ strongly agree. The mean score is 2.97 and the standard deviation is 0.58 .

The third statement is indicated that less than $26 \%$ disagree with it. In addition to this, over $74 \%$ agree with the statement. The mean score is 2.95 and the standard deviation is 0.83 .

The last question in the table 7 displays that the majority of responses support the statement, $6.8 \%$ strongly disagree and $29.6 \%$, while $52.3 \%$ agree and $11.8 \%$ agree. The mean score is 2.68 and the standard deviation is 0.59 .

4.8 Language Skills

When language teaching is discussed, it can be found that it generally makes up of four skills (listening, speaking, reading and writing). The questionnaire displays five questions to evaluate to what extent English for Iraq is adopted to improve four skills. Besides, it enables the sixth class students to communicate with English as a foreign language.

4.8 Language Skills Table (8)

\begin{tabular}{|c|c|c|c|c|c|c|c|}
\hline Statement & $\begin{array}{c}\mathrm{F} \\
\%\end{array}$ & $\begin{array}{c}\text { Strongly } \\
\text { disagree }\end{array}$ & Disagree & Agree & $\begin{array}{c}\text { Strongly } \\
\text { agree }\end{array}$ & Mean & St.D \\
\hline
\end{tabular}




\section{Global Proceedings Repository \\ American Research Foundation}

ISSN 2476-017X

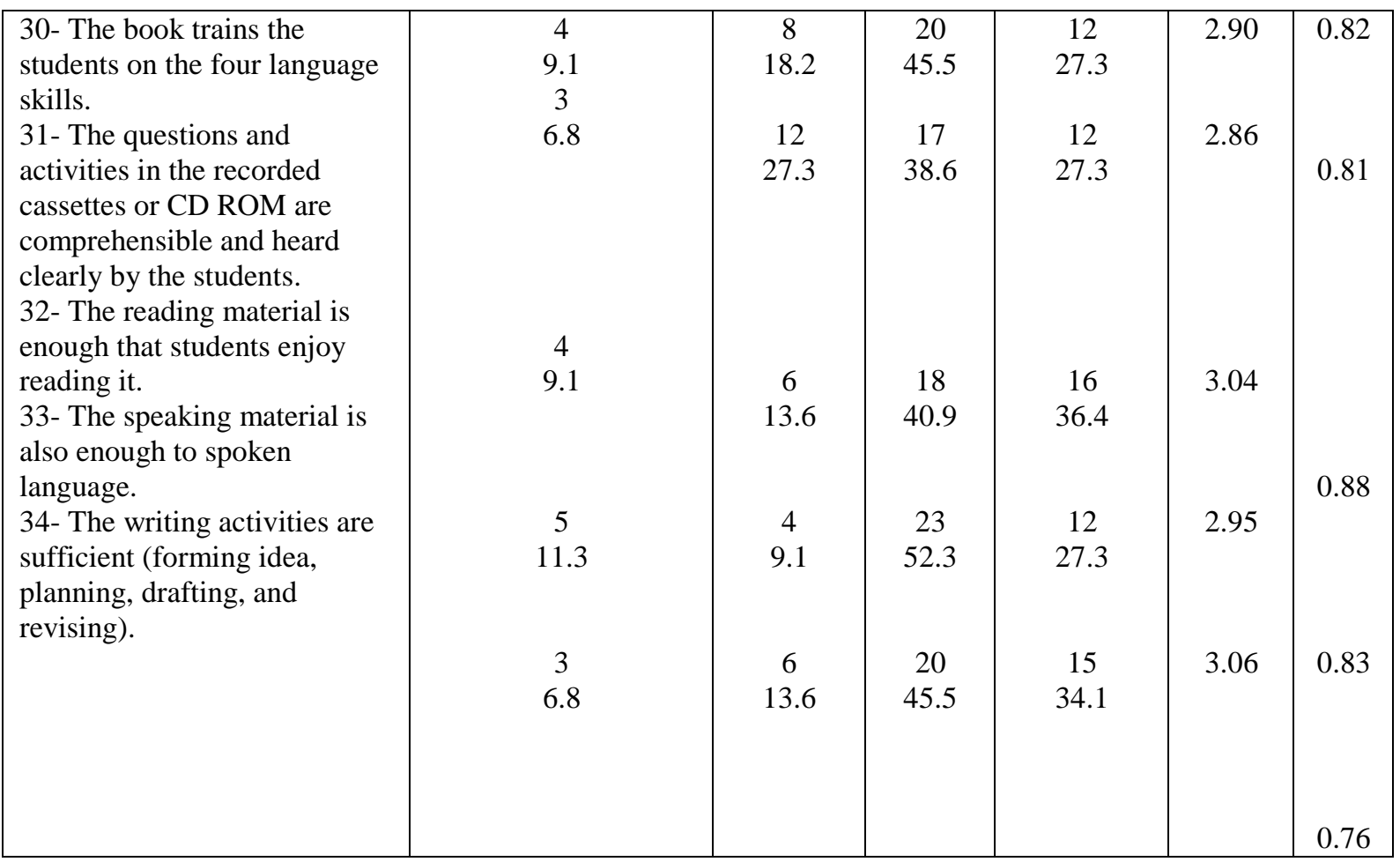

As shown in table 8, some participants do not believe the current book has not covered all four skills adequately. As the majority of participants affirming the statement, 12 participants are between strongly disagree and disagree (27.3\%). On the other side, 32 out of 44 participants believe that all four skills are covered, they are represented in supporting on the statement by the rate more $72 \%$ between agree and strongly agree. The mean score is 2.90 and standard deviation is 0.82 .

Concerning with the second question, The results indicate that the majority of responses support the item. 9.1\% strongly disagree and 18.2 disagree, while $45.5 \%$ agree and $27.3 \%$ strongly agree. The mean score is $2.86 \%$ and the standard deviation is 0.81 .

There is discussion that whether students enjoy in reading the passages of the textbook or not. The majority of teachers support the statement. 9.1\% strongly agree and $13.6 \%$ disagree, as $40.9 \%$ agree and $36.4 \%$ strongly agree. The mean score reaches 3.04 at a standard deviation of 0.88 .

Regarding spoken material, the results indicate the majority of responses confirm the item. They believe that spoken material makes students speak and communicate with others in real life. Over $79 \%$ out of the population is between strongly agree and agree while $20 \%$ is between strongly disagree and disagree. The mean score is 2.95 and the standard deviation is 0.83 .

The final question is contained whether the activities of writing skill are enough or not. The majority of responses are in favor of the statement. 6.8\% strongly disagree and $13.6 \%$ disagree. $45.5 \%$ agree and $34.1 \%$ 


\section{Global Proceedings Repository \\ American Research Foundation}

ISSN 2476-017X

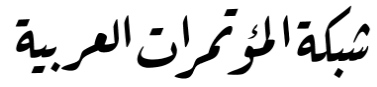

http://arab.kmshare.net/

AR F

Available online at http://proceedings.sriweb.org

strongly agree. The mean score is 3.06 and the standard deviation is

0.76 .

Arithmetic Means and Standard Deviation of Eight Categories of Evaluation Criteria Table( 9)

\begin{tabular}{|l|l|l|l|}
\hline Main categories & $\mathrm{N}$ & Mean & St.D \\
\hline 1- The appearance of the Book & 44 & 3.09 & 0.55 \\
2- The Clarification and Design & 44 & 2.81 & 0.76 \\
3- Supplementary and Material & 44 & 3.05 & 0.69 \\
4- Objectives & 44 & 2.82 & 0.73 \\
5- Subject Matter & 44 & 2.80 & 0.71 \\
6- Language Content & 44 & 2.73 & 0.74 \\
7- Socio-cultural Content & 44 & 2.88 & 0.67 \\
8- Language Skills & 44 & 2.96 & 0.82 \\
\hline
\end{tabular}

The above table 9 displays that eight domains are used in the questionnaire, 34 statements formulated positive response. This is shown that positive responses of the teachers are given for more $71 \%$ in the current study. It has been said that teachers are very good for guessing because they communicate with EFL materials directly.

Through table 9, the results that the items of the appearance of the book categories had the highest mean as the items of language content had the lowest mean.

Besides, it has obviously been chosen eight items as the lowest means less than 2.81. These items are considered weak, which represent $29 \%$ in this study because they had negative responses of teachers as shown in table 10 .

Items with the Lowest Means Table (10)

\begin{tabular}{|c|l|l|}
\hline $\mathrm{N}$ & \multicolumn{1}{|c|}{ Items } & \multicolumn{1}{|c|}{ Mean } \\
\hline $1-$ & $\begin{array}{l}\text { The book includes an appropriate materials for teaching pronunciation. } \\
\text { The clarifications are clear and simple details that may confuse the students. }\end{array}$ & 2.22 \\
2- & $\begin{array}{l}\text { The objectives are selected accurate and clear. } \\
\text { The book explains positive of attitude, behaviour, reaction, traditions, habits and value } \\
\text { in the Iraqi society. }\end{array}$ & 2.54 \\
4- & $\begin{array}{l}\text { The developmental objectives are identified at initial of each lesson. } \\
\text { The subjects of the book are various and appropriate to students at sixth class for their } \\
\text { 5- } \\
\text { needs and interests. } \\
\text { The size looks convenient for students to handle. }\end{array}$ & 2.63 \\
6- & $\begin{array}{l}\text { The clarifications are typed close sufficient to the text and related to the content for } \\
\text { assisting the students realize the typed text. }\end{array}$ & 2.64 \\
7- & & 2.70 \\
$8-$ & & 2.75 \\
\hline
\end{tabular}

5. Conclusion

The current study has evaluated the efficiency sixth class secondary English textbook for Iraqi students as seen by teachers. " English for Iraq" is used currently in secondary school. It has been considered good because it meets interests and needs of students in developing their abilities in learning English as a foreign language. Although the obtained results have got very positive and the majority of teachers' attitudes consider concerning with its appearance of the book, the clarification and design, supplementary and materials, objectives, subject matters, language content, socio-cultural, and language skills. Moreover ,the materials for 


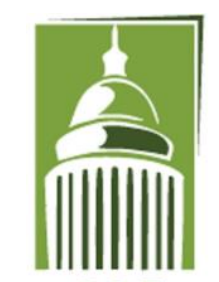

AR F

\section{Global Proceedings Repository \\ American Research Foundation}

ISSN 2476-017X

Available online at http://proceedings.sriweb.org

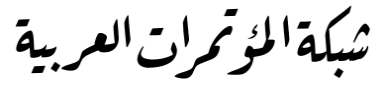

http://arab.kmshare.net/

teaching pronunciation is inappropriate to teach sixth class Iraqi students at secondary schools according the point of views of teachers.

However, the current study suggests as following:

1- Designing an appropriate material for teaching pronunciation

2- Adding a list of irregular verbs because the majority of students are not familiar with changing conditions of verbs especially in the use of tenses.

3- Replacing one of the short stories because both of them are about tragically events and sad ends .

Bibliography

Agudo, J.D.M. (2014) English as a Foreign Language Teacher Education: Currently Perspective and Challenges. Nederland :Rodopi.

Al-Mahrooqi,R. and Denman, C. (2015) Issues in English Education in the Arab World. UK: Cambridge Scholars.

Al-Sowat, H. (2012) An Evaluation of English Language Textbook " Say It In English" for First Year Intermediate Grade in Saudi Arabia. Journal of studies in curriculum and supervision, Vol.3 No.2p.p 332 413.

Azizifar, A. , Kooshan, M. and Lotif, A. (2010) An Analytical Evaluation of Iranian High School ELT

Textbook from 1970 to the Present. Journal of Procedia Social and Behavioral Sciences Vol.7, p.p36-44.

Becerra, C. (2006) Materials Assessment : A shared Responsibility among Teachers and Students. National University of Foreign language. Vol.7, p.p 31-45.

Brace, I (2008) Questionnaire Design: How to Plan, Structure and Write Survey Materials for Effective Market Research. $2^{\text {nd }}$ ed. India: Replika press pvt Ltd

Grant, N. (1987) Making the Most of Your Textbook. London: Longman.

Hutchison, T. and Torres, E.(1992) The Textbook as Agent of Change. EFL Journal Vol.48/4. Oxford university press.

Kiely, R. and Rea-Dicken, p.(2005) Program Evaluation Language Education. London: Licensing Agency.

Lawrence, W. p. (2011) Textbook Evaluation: A Framework for Evaluating the Fitness of the Hong Kong New Secondary School (NSS) Curriculum. Unpublished thesis. Hong Kong: university of city.

Leitzmann, M., F., Jochem, C. and Schmid, D.(2018) Sedentary Behaviour Epidemiology. Switzerland: Springer International publishing.

Madaus, G.,F. Scriven, M.,S. and Stufflebeam (1983) Evaluation Models: Viewpoints on Education and Human Services Evaluation. $1^{\text {st }}$ ed. Nederland: Kluwer.

McDonough, J., Shaw, C. and Masuhara, H.(2013) Materials and Methods in ELT: A Teacher;s Guide. $3^{\text {rd }}$ ed. UK: John Wiley and sons, Inc.

Mohmood, K. (2009) Indicators for a Quality Textbook Evaluation Process in Pakistan. Journal of Research and Reflections in Education. Vol.3, No.2, p.p 158-17.

Pathak, R.P. (2008) Methodology of Educational Research. New Delhi: Atlantic press.

Ramsden, p. (2003) Learning to Teach in Higher Education. 2 $2^{\text {nd }}$ ed. London: Taylor and Francis group. 


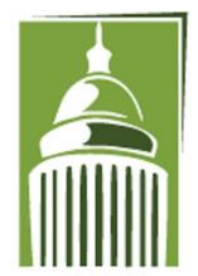

A R F

\section{Global Proceedings Repository \\ American Research Foundation}

ISSN 2476-017X

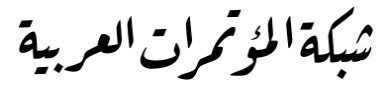

http://arab.kmshare.net/

Available online at http://proceedings.sriweb.org

Rea-Dickens, P. and Germaine, k. (1992) Evaluation. $1^{\text {st }}$ ed. China: Oxford university press.

Richards, J. C. and Renandya , W.A. (2002) Methodology in Langauge Teaching: An Anthology of Current Practice. Cambridge university press.

Sabzalipour, B. and Koosha, M. (2014) The Evaluation of Iranian High School English Textbook from the Perspective of Teachers. Asian Journal of Social sciences and Humanities. Vol.3 No.3 , p.p 215-228.

Sheldon, L.E. (1988) Evaluating ELT Textbooks and Materials. EFT Journal 42 No.4 Oxford university.

Spolsky, B. and Moon, Y. C. (2012) Primary School English- Language Education in Asia: from Policy to Practice. New York: Taylor and Francis group.

Thomas, J.R., Nelson, J.K and Silverman, S.J. (2011). Research Methods in Physical Activity. $6^{\text {th }}$ ed. The united states of America: Human Kinetics.

Tomlinson, B. (2003) Developing Materials for Language Teaching, $1^{\text {st }}$ ed. Great British: Crown well press.

Tomlinson, B. (2008) English Language Learning Materials: Acritical Review. Great British: Biddle, Ltd.

Tomlinson, B. and Musuhara, H. (2018) The Complement Guide to the Theory and Practice of Materials Development for Language Learning . ${ }^{\text {st }}$. U.S.A: John Wiley and sons, Inc.

Tomlinson, C.A. (2001) How to Differentiate Instruction in Mixed-Ability Classrooms. $2^{\text {nd }}$ ed. U.S.A, Virginia: Alexandria.

Williams, D.(1983) Developing Criteria for Textbook Evaluation. EFL Journal Vol.37 No.3.

Zumbo, B.D. and Chan ,E. K. H. (2014) Validity and Validation in Social, Behavioral, and Health Sciences .Switzerland: Springer International Publishing.

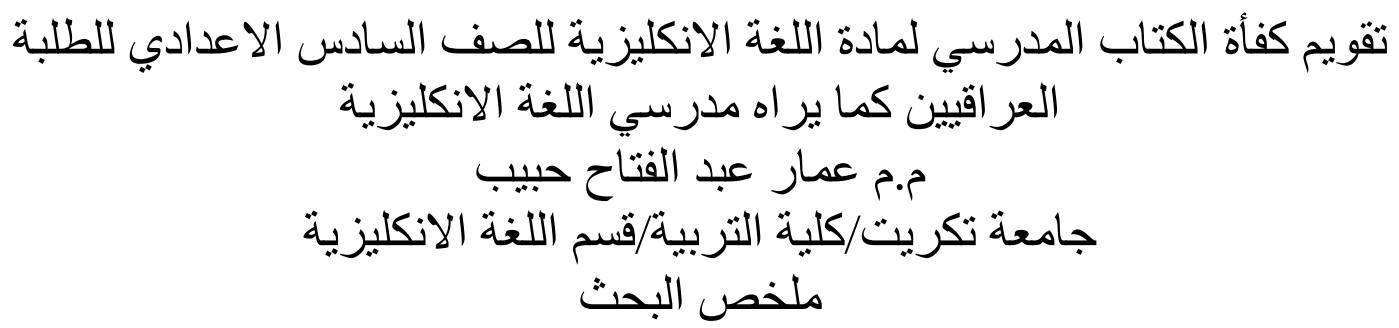

تهدف الدراسة الحالية الى تقويم كفاءة كتاب اللغة الإنجليزية للصف السادس من موجهة نظر

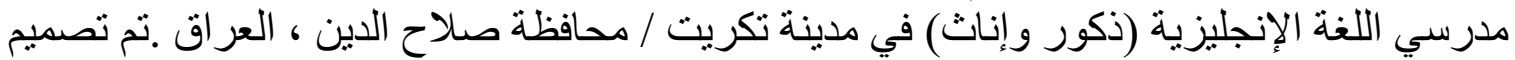

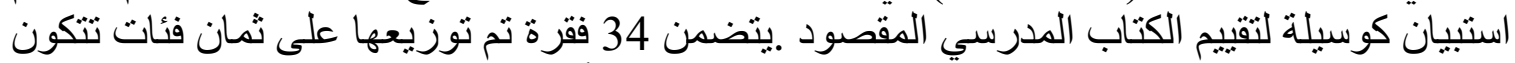

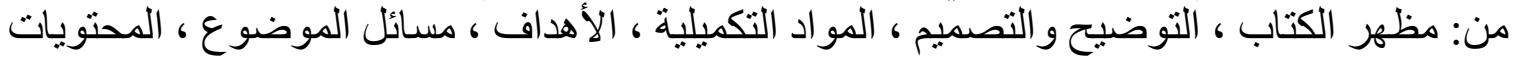




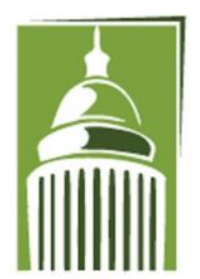

AR F
Global Proceedings Repository American Research Foundation

ISSN 2476-017X

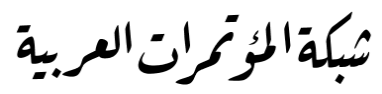

http://arab.kmshare.net/

Available online at http://proceedings.sriweb.org

اللغوية ، المحتوى الاجتماعي الثقافي و المحتويات اللغوية .أربعة و أربعون مدرساً و مدرسه (ذكور

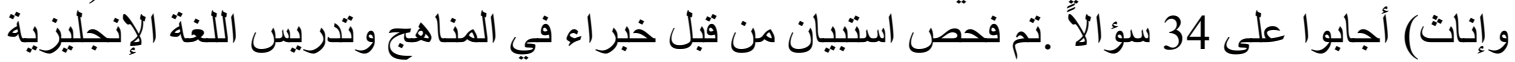

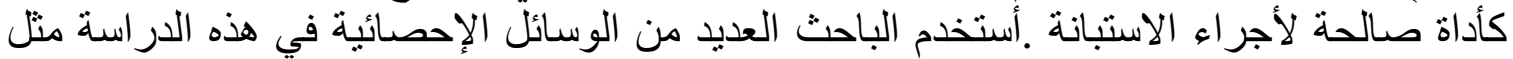

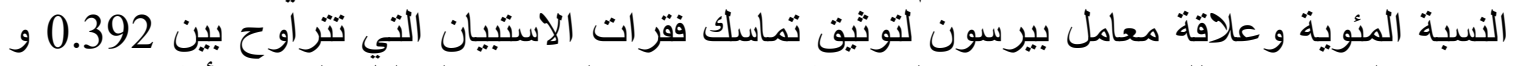

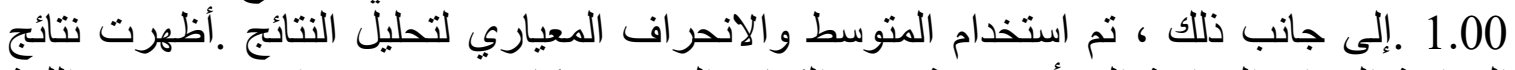

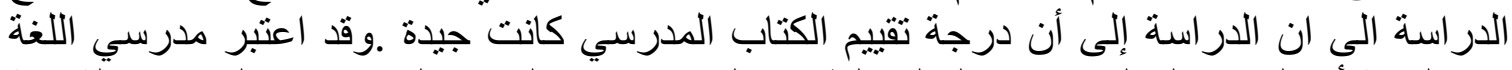

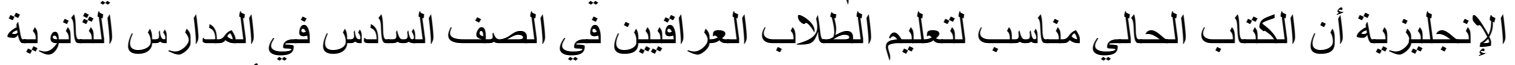

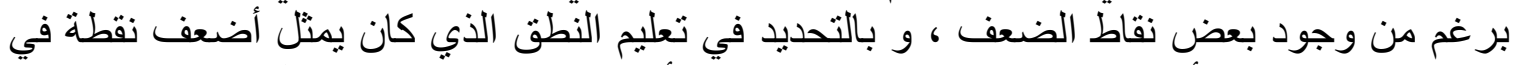

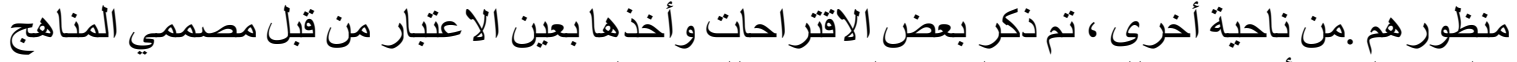
و المسؤولين الأكاديميين للتحسين الكتاب المدرسي للصف السترف السادس. 